\title{
Reverence of Community towards Grassroot Livestock Innovation: Responding to Stakeholders Need against Sub-Clinical Mastitis in Amreli District, Gujarat, India
}

\section{Becharbhai Samantbhai Devgania ${ }^{1}$, Dilipbhai Khordia ${ }^{1}$, Mahesh B Chodvadiya ${ }^{2}$, Ramesh Patel $^{1}$, Devesh Patel ${ }^{2}$, Amol S Kinhekar ${ }^{2}$, Pawan K Singh ${ }^{2}$, Vivek Kumar ${ }^{2}$, Bhojne, G.R ${ }^{3}$, RAVIKUMAR, R. K ${ }^{*}$, VIPIN KUMAR ${ }^{2}$}

\section{${ }^{1}$ Society for Research and Initiatives for Sustainable Technologies and Institutions, AES Boys Campus, Abmedabad, Gujarat; ${ }^{2}$ National Innovation Foundation-India, Satellite Complex, Abmedabad, Gujarat 380 015; ${ }^{3}$ Nagpur Vet- erinary College, MAFSU, Nagpur, Maharashtra, India.}

\begin{abstract}
Mastitis is an ailment of economic importance affecting livestock worldwide. Several initiatives have been initiated globally through investment of highly skilled human resource along with unconstrained financial support. The nature of disease, cost of medication, difficulties in reaching out to needy livestock population and accessibility to diagnostic facilities are main impediments. Innovations from creative individuals in similar setting can address such difficulties better. Hence, listening to farming communities will enhance the scope of intervention and leverage experimental learning in society. Indigenous livestock system sustained by outstanding traditional livestock holders can complement efforts of scientific community. Appreciating the role, mainstreaming of indigenous veterinary medications has been revitalized. However, successful evidence of communities' role in bringing out suitable researchable issues, and response to meet, share and discuss with them were limited. The study illustrates successful outcome to bring desired attention in this area. During this engagement with civil society a novel innovative medicine coded AHP/BSD/SCM in treatment of sub-clinical mastitis was evaluated and was found effective. A specific research question posed by indigenous healer provided different perspective to control mastitis. This research study offers art of engaging different stakeholders to construct a meaningful situation for expressing and implementing creative, affordable technologies. It highlights the role of society in sharing a solution that has been collectively preserved by them and essential direction to formal system.
\end{abstract}

Keywords | Innovation, Sub-clinical mastitis, Indigenous, Creative society, Community

Editor | Kuldeep Dhama, Indian Veterinary Research Institute, Uttar Pradesh, India.

Received | September 02, 2015; Revised | October 05, 2015; Accepted | October 06, 2015; Published | November 14, 2015

*Correspondence | Ravikumar R K, National Innovation Foundation India, Satellite Complex, Ahmedabad, Gujarat, India; Email: ravikumar@nifindia.org

Citation | Devgania BS, Khordia D, Chodvadiya MB, Patel R, Patel D, Kinhekar AS, Singh PK, Kumar V, Bhojne GR, Ravikumar RK, Kumar V (2015). Reverence of community towards grassroot livestock innovation: Responding to stakeholders need against sub-clinical mastitis in Amreli District, Gujarat, India. Adv. Anim. Vet. Sci. 3(12): 689-693.

DOI | http://dx.doi.org/10.14737/journal.aavs/2015/3.12.689.693

ISSN (Online) | 2307-8316; ISSN (Print) | 2309-3331

Copyright $(92015$ Devgania et al. This is an open access article distributed under the Creative Commons Attribution License, which permits unrestricted use, distribution, and reproduction in any medium, provided the original work is properly cited.

$\mathrm{M}$ astitis is a disease of economic importance causing havoc in dairy sector throughout the world. National mastitis control program envisages minimizing spread of infection, protecting mammary gland tissue and curtailing entry of pathogens through teat orifice. Farm productivity has been limited with lack of appropriate technologies to meet location specific requirements (Kadivendi et al., 2015). Periodic assessment of milk is important to know the health status of udder (Syed et al., 2009). Dairy farmers differ in undertaking risk, seeking alternative source of employment and level of motivation in any region. The enhanced occurrence of coagulase negative staphylococci (CNS) is cause of concern (Reyher and Dohoo, 2011; El-Jakee et al., 2013). Incidence of subclinical mastitis (SCM) upto 50\% in cows was reported in different regions (Gianneechini et al., 2002; Alhussien et al., 2015). In India, SCM occurs forty times more than clinical form with annual economic loss of Rs. 4365.32 crore (NAAS, 2013; Bhanderi et al., 2014). These findings reflect that SCM needs to be given adequate attention (Abrahmsen et al., 
2014). The role of trace elements to reduce pathogens in mastitis affected udder was studied (Ibtisam et al., 2006). There are limited studies to compound these factors and to suggest suitable interventional strategies for control. of mastitis.

There is imminent necessity to find new tools to overcome resistance of causative agents and minimize antibiotic residues (Pieterse and Todorov, 2010). The veterinary profession is concerned with potential risk in transfer of such resistance to humans (FDA, 1996). Alternative approach to control SCM is felt as it causes reduced milk yield and quality (Bhikane et al., 2011). More than twenty percent of farmers reported use of homeopathic medication to control mastitis (Egan, 1998). The values cherished by local communities so as to solve location specific problem without outside support were shared (Gupta et al., 2003). The evaluation of clinical efficacy of Azadirachta indica (neem) in controlling udder infection emphasized need for alternative therapy (De and Mukherjee, 2009). Natural products offered quality approach for prevention and treatment of mastitis (Nurdin et al., 2011; Nagwa et al., 2014). The protective role of indigenous veterinary system towards environment needs to be given importance (Ravikumar et al., 2015). Realistic need and aspiration of farming community in catering to quality veterinary health care need to be addressed. Social mobilization is paramount for seeking benefit of new ideas and skills among members ( $\mathrm{Ng}$ et al., 2010). The research study was conducted to share a suitable strategy to focus on delivery of veterinary health system relying on farmer's innovation with a specific reference to SCM. The study also illustrated the need for institutions to acknowledge and compassionately embrace creative solutions from society.

The study was conducted at Amarapur, Gandhinagar district of Gujarat state. Animals in the livestock farm were examined clinically and California Mastitis Test (CMT) was conducted for identification of sub-clinical mastitis (SCM). Throughout the experiment holding of CMT paddle was maintained at the same position for collection of milk. The collected milk represents the quarter foremilk (QFM) of udder. The results of each of the quarter were observed immediately. The reaction to the CMT test reagent was scored in order of severity as Negative (-), Suspicious or Trace (+/-) and Positive [+ (weak positive), ++ (Distinct positive), +++ (Strong positive)] as per standard protocol (Pardo et al., 2007; Beheshti et al., 2011). The first stripping of milk was carefully avoided and about $3 \mathrm{ml}$ of milk was directly stripped into the CMT paddle. Equal quantity of CMT reagent was added to each chamber of the paddle and observed for reaction (NVC, 2009). The reaction was aided by swirling the paddle, as well as tilting the paddle from side to side as per standard protocol. The degree of change in colour, thickening and gel formation were observed for 25 seconds with slight modification in duration (Reddy et al., 2014).

The CMT positive samples of QFM were marked as subclinical mastitis. Udder and teats were observed for any debris so as to eliminate any other cause for mastitis. None of the animals was in the dry period or approaching calving. The CMT paddle was emptied with its content and cleaned with cold water before proceeding for examining next animal. The medication AHP/BSD/SCM was applied topically over affected udder surface twice daily for 4 days. Further, the study attempted to explore nature of social participation upon sharing the scientific validation in the place of knowledge origin and to understand embedded values by community in acknowledging indigenous system. The implications of such arrangements in generating new form of knowledge or sustaining creativity at farming communities were assessed.

A total of eleven animals and forty three quarters were examined and seven animals and twenty six quarters were found positive for subclinical mastitis (Table 1). The rate of quarterwise prevalence of SCM was 60.46 percent among the experimental animals. Among 26 quarters positive for CMT, 16 (61.53\%) had shown weak positive and 10 (38.46\%) had distinct positive reaction. Studies indicated that level of biochemical response to infection at udder level used to be higher than at quarters (Hamann et al., 2010). All seven animals positive for SCM were subjected to testing clinical efficacy of indigenous medication.

Table 1: CMT evaluation reflecting degree of SCM among experimental animals: [Day 0 (Before treatment)]

\begin{tabular}{lllllll} 
Sr. No. & $\begin{array}{l}\text { Animal No. with de- } \\
\text { scription }\end{array}$ & \multicolumn{4}{l}{ Udder Quarters } \\
& 198252 (Kankrej) & RF & LF & RH & LH \\
1 & + & ++ & ++ & + \\
\hline 2 & 684207 (Crossbred) & + & + & ++ & ++ \\
\hline 3 & 198480 (Crossbred) & ++ & + & ++ & + \\
\hline 4 & 198296 (Crossbred) & + & Blind & + & + \\
\hline 5 & 198365 (Kankrej) & ++ & + & + & + \\
\hline 6 & No tag (Crossbred) & ++ & ++ & + & + \\
7 & 198321 (Crossbred) & + & ++ & + & - \\
\hline
\end{tabular}

Twenty six quarters were observed for evaluating impact of medication over sub-clinical mastitis (Table 2). It was found that 92.30 percent $(n=24)$ of quarters were negative for CMT on $5^{\text {th }}$ day of observation. One of the positive quarters for CMT did not show any change (3.86 percent, $\mathrm{n}=1$ ), whereas another quarter showed some improvement, however, it was suspected for SCM (Trace). The severity of SCM condition was reduced after topical application of AHP/BSD/SCM for a period of four days. This may 
be important tool for overall intervention program as attempts like antibiotic, vaccine have their own limitation. Unhygienic intramammary treatment was found responsible for mycotic mastitis and clinical mastitis with poor or no response to conventional antibiotics (Langer et al., 2014). In fact, the national policy attributed limited use of vaccine in mastitis control strategies to inability to prevent new infections (NAAS, 2013). An in vitro effective antibiotic might not give same results under clinical conditions. Hence, these environmental friendly technologies are appropriate for small holder production system (Ravikumar et al., 2015a).

Table 2: Impact of medication against SCM

\begin{tabular}{|llll|}
$\begin{array}{l}\text { Sr. } \\
\text { No. }\end{array}$ & $\begin{array}{l}\text { Nature of CMT } \\
\text { reaction }\end{array}$ & $\begin{array}{l}\text { Before } \\
\text { treatmenty } \\
(\text { Day 0) }\end{array}$ & $\begin{array}{l}\text { After treat- } \\
\text { ment } \\
\text { (Day 5) }\end{array}$ \\
\hline 1 & Trace (+/-) & 00 & 01 \\
\hline 2 & Weak positive (+) & 16 & 01 \\
\hline 3 & Distinct positive (++) & 10 & 00 \\
\hline 4 & Strong positive $(+++)$ & 00 & 00 \\
& Total & 26 & 02 \\
\hline & Recovery (\%) & 92.30 & \\
\hline
\end{tabular}

It is pertinent to share scientific findings to knowledge holders as a part of ethical research system. Marfo (2013) argued that pragmatic policies can be laid by understanding dynamics of human security. The social needs have to be addressed for developmental initiatives. Various efforts were made by National Innovation Foundation-India in sharing and diffusion of research findings in controlling ailments like endoparasite, ectoparasite infestation, enhancing poultry immunity by involving civil society (Bharwad et al., 2015; Gaikwad et al., 2015; Patel et al., 2015). Sharing such findings with knowledge holders and their society would create empathetic environment that can foster innovation systems (ADB, 2014). In this respect, an interactive meeting with villagers and knowledge holder was called in the month of July, 2015, at Hadida village, Savarkundla Taluk of Amreli district, Gujarat. Forty participants from the village had assembled and the research team shared scientific efficacy of the medication sustained by knowledge holder Shri Becharbhai Samantbhai Devgania. Investigators felt overwhelmed upon visualizing community response to discus and acknowledge efforts of traditional livestock healer. The general feeling of marginalization of knowledge system by community in advent of modern medicine was not noticed. These natural scientists sustained technologies that are easy to adapt by farmers or make minimum demand (Gupta, 1995).

During the meeting dairy farmers indicated that they spend on an average 22 USD for treatment of mastitis along with risk of medicine failure. The discussion revealed that regular availability of skilled manpower has been a concern in remote locations. This knowledge system had contributed towards social responsibility by reducing distress and cost of input owing to mastitis. The difficulties narrated by dairy farmers had motived knowledge holder to share better ways to control mastitis. His opinion was that administration of same medication, fifteen days before expected date of calving can minimize incidence of mastitis, as the dry period was crucial due to physiological changes occurring for next lactation. Arruda et al. (2013) shared that incidence of new intra-mammary infections (IMI) was to the tune of 25 percent during dry period. Studies also indicated the need to survey dry cow udder for effective mastitis control (Dufour et al., 2011). It was also illustrated that most common pathogen isolated during dry period was coagulase negative Staphylococcus (CNS). Hence, the tacit knowledge shared by traditional livestock healers needs to be verified so as to gain from such societal learning.

Knowledge holder acted as gatekeeper through their expertise and ability to identify potential problem (Fleming and Marx, 2006). This reinforces the need for generation and sustaining of mutual trust so as to understand technical cues from knowledge holders (Ravikumar, 2007). This is in concurrence to earlier findings reported elsewhere. The documented video of this explanation by knowledge holder is available with the corresponding author who carried out the discussion. Thus interactive meeting along with shared scientific findings to villagers infront of custodian of knowledge had resulted in sharing of new knowledge. During the process, characteristic of sustainable entrepreneurship interms of innovation by applying social practices as indicated by Kardos (2012) was illustrated.

Treatment with antibiotic has been concern as it affects dairy products and pose public health hazard (El-Jakee et al., 2013). The need for dry cow therapy has been advocated to control subclinical mastitis (Barua et al., 2014). These knowledge systems were researched that enabled sustenance of novel practice by society (Ravikumar et al., 2004). Studies had indicated that scientific opportunities need to be generated to understand indigenous knowledge system beyond narrated claim(s) (Ravikumar et al., 2015b). Studies need to be undertaken to understand the efficacy of this novel medication against intramammary infection (IMI) during dry period, its role against common pathogens and nature and incidence of IMI after calving.

The experimental nature of farming community to overcome problem through their understanding of existing solution needs to be tapped. Farmers can be proud of their innovation and this results in better adoption (Ravikumar 
et al., 2002). Generation of such social capital and engagement of people in group at door step of creative people will open up new knowledge for experimentation. However, national policy in India could not reflect the strength of this creativity in rural society in its policy measures and recommendations (NAAS, 2013). The need for institutional transformation through influence of civil society is felt (Prasad, 2005). Further, it is paramount for youth to learn from these opportunities outside formal system so that they can cope up with difficulties (Tripon, 2014). Such trait of cohesive participation needs to be nurtured and positively maneuvered for developing suitable policies (Rainer, 2014). Scaling up of these scientifically validated innovations can be enhanced through linking with dairy societies (Ravikumar et al., 2015c).

The study delved upon farming communities concern, acknowledging local solutions, distinguishing creative individuals, scientific evaluation in clinical situation, sharing the results to community and enlarging scope for evolution of wider knowledge. The study recorded a prevalence rate of subclinical mastitis as high as sixty percent. The research study demonstrated an effective novel topical medication based on indigenous knowledge system. These medications are readily available, easy to develop and administer. It needs to be part of general management practices at cow side. The study also demonstrated the response of society in recognizing service of local knowledge system. Acknowledging knowledge holder by civil society as well as other stakeholders is paramount for sustaining creativity at farming community. The social capital endeavored by local knowledge system have to be harnessed for developing suitable solutions. It is difficult for public system alone to cater quality health care to vastly distributed livestock population. Hence, efforts need to be complemented with the help of the scientific community so as to unearth new knowledge domain by engaging farmers on larger scale.

\section{ACKNOWLEDGEMENT}

We acknowledge Gram Bharti, Amrapur, Gandhinagar, Gujarat for permitting to conduct experiment in livestock farm and Dept. of Veterinary Microbiology, Animal Biotechnology Teaching \& Research Cell, Nagpur Veterinary College, Maharashtra Animal \& Fishery Sciences University (MAFSU), Nagpur for providing CMT reagents.

\section{CONFLICT OF INTEREST}

Authors declare that they have no conflict of interest.

\section{AUTHOR'S CONTRIBUTION}

All authors contributed equally to the manuscript.

\section{REFERENCE}

-Abrahmsen M, Persson Y, Kanyima BM, Bage R(2014). Prevalence of subclinical mastitis in dairy farms in urban and peri-urban areas of Kampala, Uganda. Trop. Anim. Health Prod. 46: 99-105. http://dx.doi.org/10.1007/s11250-0130455-7

-ADB (2014). Creative productivity index, analysing creativity and innovation in Asia, a report by the economist intelligence unit for the Asian Development Bank (ADB).

-Alhussien M, Kaur M, Manjari P, Kimothi SP, Mohanty AK, Dang AK (2015). A comparative study on the blood and milk cell counts of healthy, subclinical and clinical mastitis Karan Fries cows. Vet. World. 8(5): 685-689. http://dx.doi. org/10.14202/vetworld.2015.685-689

-Arruda AG, Godden S, Rapnicki P, Gorden P, Timms L, Aly S.S, Lehenbauer TW, Champagne J (2013). Randomized noninferiority clinical trial evaluating 3 commercial dry cow mastitis preparations: I. Quarter-level outcomes. J. Dairy Sci. 96(7): 4419-4435.

-Barua M, Prodhan, MAM, Islam K, Chowdhury S, Hasanuzzaman M, Imtiaz MA, Das, GB (2014). Subclinical mastitis prevalent in dairy cows in Chittagong district of Bangladesh: Detection by different screening tests. Vet.World.7(7): 483-488. http://dx.doi.org/10.14202/ vetworld.2014.483-488

-Beheshti R, Eshratkhah B, Shayegh J, Ghalehkandi JG, Dianat V, Valiei K (2011). Prevalence and etiology of subclinical mastitis in buffalo of the Tabriz region, Iran, J. Am. Sci. 7(5): 642-645.

-Bhanderi BM, Garg MR, Goswami A (2014). Effect of supplementing certain vitamins and chelated trace minerals on reducing incidence of subclinical mastitis in crossbred cows, Indian J. Anim. Sci. 85(2): 178-182.

-Bharwad D, Vasan V, Kinhekar A.S, Kumar V, Ravikumar R K and Kumar V. 2015. Therapeutic evaluation of indigenous veterinary medication for endoparsite infestation in bovines under field condition. Indian J. Appl. Res. 5(4): 755-756.

-Bhikane AU, Hase PB, Syed AM, Ghoke SS, Devangare AA, Awandkar SP (2011). Efficacy of herbomineral formulation in subclinical mastitis in crossbred cows. Indian Vet. J. 88(10): 171-172.

-De UK, Mukherjee R (2009). The inhibitory response of Azadirachta indica extract on nitric oxide production by milk leukocytes during clinical mastitis. Vet. Archiv. 79(1): 41-50.

-Dufour S, Fréchette A, Barkema HW, Mussell A, Scholl DT (2011). Effect of udder health management practices on herd somatic cell count. J. Dairy Sci. 94 (2): 563-579. http:// dx.doi.org/10.3168/jds.2010-3715

-Egan J (1998). Homoeopathic mastitis control: A study on the uptake and efficacy of products in the Republic of Ireland, In Proceedings of the British Mastitis conference, Axient/ Institute for Animal Health, Milk Development Council, Novartis Animal health, 22-28.

-El-Jakee JK, Aref NE, Gomaa A, El-Hariri MD, Galal HM, Omar SA, Samir A (2013). Emerging of coagulase negative staphylococci as a cause of mastitis in dairy animals: An environmental hazard. Int. J. Vet. Sci. Med. 1(2): 74-78. http://dx.doi.org/10.1016/j.ijvsm.2013.05.006

-FDA (1996). Judicious use of antimicrobials for dairy cattle veterinarians, food and drug administration center for veterinary medicine (FDA), Dept of Health and Human Services and American Veterinary Medical Association, Pp. 6.

-Fleming L, Marx M (2006). Managing creativity in small worlds, California management review. 48(4): 6-27.

- Gaikwad SLR, Ramana DN, Solanki RP, Khatana LB, Gohil 
NK., Vasava NG, Patel P, Sahay NS, Patel J, Ravikumar RK, Singh PK, Kinhekar AS, Kumar V (2015). Efficacy of an indigenous veterinary medication to control endoparasite infestation in clinically diagnosed large ruminants affected with diarrhoea amongst field conditions, Gujarat, India. Euro. J. Exp. Biol. 5(5): 81-84.

- Gianneechini R, Concha C, Rivero R, Delucci I, Lopez JM (2002). Occurrence of clinical and subclinical mastitis in dairy herds in the west littoral region in Uruguay. Acta. Vet. Scand. 43: 221-230. http://dx.doi.org/10.1186/1751-014743-221

- Gupta AK, Sinha R, Koradia D, Patel R, Parmar M, Rohit P, Patel H, Patel K, Chand VS, James TJ, Chandan A, Patel M, Prakash TN, Vivekanandan P (2003). Mobilizing grassroots' technological innovations and traditional knowledge, values and institutions, articulating social and ethical capital. Futures. 35: 975-987. http://dx.doi.org/10.1016/S00163287(03)00053-3

- Gupta AK (1995). Survival under stress: Socioecological perspectives on farmers' innovations and risk adjustments. In. Warren M., Slikkerveer, L.J. and Borkensha, D (Eds). The cultural dimension of development, Intermediate Technology Publications Ltd., London. Pp. 407-418.

-Hamann J, Lind O, Bansal BK (2010). Determination of onfarm direct cell count and biochemical composition of milk in buffaloes, In: Milk Production, proceedings of $9^{\text {th }}$ World Buffalo congress, Buenos Aires, Abril, Argentina. Pp. 541542.

-Ibtisam EM, El Zubeir OA, El Owni O, Mohamed GE (2006). Effect of mastitis on trace elements of milk and blood serum in Friesian dairy cows. Asian J. Anim. Vet. Adv. 1: 82-85. http://dx.doi.org/10.3923/ajava.2006.82.85

-Kadivendi M, Maheswari R, Ravikumar RK, Chauhan MM, Kinhekar AS, Kumar V, Kumar V (2015). Integrated approach for engaging farming community-opportunities and challenges for low cost inputs. Int. J. Agri.Innov. Res. 3(6): 1691-1695.

-Kardos M (2012). Emerging markets queries in finance and business, the relationship between entrepreneurship, innovation and sustainable development: Research on European Union Countries. Procedia Econ. Financ. 3: 10301035. http://dx.doi.org/10.1016/S2212-5671(12)00269-9

-Langer A, Ahuja A, Bihani DK (2014). Diagnosis of mycotic mastitis in cow. Ruminant Sci. 3(2): 235-236.

- Marfo S (2013. Human security: A key to a meaningful conflict resolution and development in a New Ghana. Procedia Soc. Behav. Sci. 91(10): 545-555. http://dx.doi.org/10.1016/j. sbspro.2013.08.453

-NAAS (2013). Mastitis management in dairy animals. Policy Paper No. 61, National Academy of Agricultural Sciences, New Delhi. Pp.12.

- Nagwa SA, Mona SZ (2014). New approaches in control of mastitis in dairy animals. Life Sci. J. 11(2): 275-277.

-Ng L, Jost C, Robyn M, Dhakal IP, Bett B, Dhakal P, Khadkha R (2010). Impact of livestock hygiene education programs on mastitis in smallholder water buffalo (Bubalus bubalis) in Chitwan, Nepal. Prev. Vet. Med. 96 (3-4): 179-185. http:// dx.doi.org/10.1016/j.prevetmed.2010.06.012

-Nurdin E, Amrelia T, Makin M (2011). The effects of herbs on milk yield and milk quality of mastitis dairy cow. J. Indonesian Trop. Anim. Agri. 36(2): 104-108.

- NVC (2009). Hands on training to field veterinarians on 'Recent disease diagnostic techniques', $16^{\text {th }}-19^{\text {th }}$ Nov., Dept of Microbiology \& Animal Biotechnology, Nagpur Veterinary College, Maharashtra Animal \& Fishery Sciences University,
Nagpur. Pp. 23-24.

-Pardo RB, Sanchez GM, Filho AN, Santos TAB, Langoni H, Tonhati H, Ferreira EBS, Ravena DL, Oliveira MEA, Sturion DJ (2007). Microbial evaluation of milk samples positive to California mastitis Test in dairy buffalo cows (Buballus bubalis). Ital. J. Anim. Sci. 6(2): 884-887.

-Patel JB, Patel S, Patel P, Ravikumar RK, Kinhekar AS, Kumar V, Ingle VC, Awandkar S, Tembhurne PA, Kumar V (2015). Poultry immunity against Ranikhet Disease Virus (RDV) A case study of an indigenous poultry medication in village production systems of Maharashtra, India. J. Chem. Pharm. Res. 7(4): 1040-1042.

-Pieterse R, Todorov SD (2010). Bacteriocins-Exploring alternatives to antibiotics in mastitis treatment. Brazilian J. Microbiol. 41: 542-562. http://dx.doi.org/10.1590/S151783822010000300003

- Prasad CS (2005). Science and technology in civil society: Innovation trajectory of spirulina algal technology, Economic and Political Weekly, 4363-4372.

- Rainer S (2014). Social participation and social engagement of elderly people. Procedia Soc. Behav. Sci. 116: 780-785. http://dx.doi.org/10.1016/j.sbspro.2014.01.297

- Ravikumar RK, Kinhekar AS, Kumar V (2015). Study of efficacy of veterinary medication for effective rumen function: A strategy to minimize greenhouse gas emission. Global J. Res. Anal. 4(4): 1-2.

- Ravikumar RK, Kumar V, Choudhary H, Kinhekar AS, Kumar $\mathrm{V}$ (2015a). Efficacy of indigenous polyherbal ectoparasiticide formulation against hard tick infestation in cattle (Bos indicus). Ruminant Sci. 4(1): 43-47.

- Ravikumar RK, Kinhekar AS, Kumar V (2015b). Innovative means for regulating global warming through indigenous veterinary system: Are we missing sustainable solutions? J. Chem. Pharm. Res. 7(5): 951-954.

-Ravikumar RK, Hardev C, Kumar V (2015c). Means for retaining farming communities in semi-arid regions of Gujarat state. Agric. Update. 10(2): 158-163. http://dx.doi. org/10.15740/HAS/AU/10.2/158-163

- Ravikumar RK (2007). Understanding the healers knowledge: Taking the indigenous technology forward, In Book of Abstracts, Working group on 'Education for Innovation \& Technology', Proceeding of 'Environmental education towards a sustainable future-Partners for the Decade of Education for sustainable development', $4^{\text {th }}$ International Conference on Environmental education, 26-28th Nov, Centre for Environment Education, Ahmedabad.

- Ravikumar RK, Rao BS, Bose CHS, Sudhakar K (2004). Validity of ethnoveterinary practices adopted by farmers in Dindigul district of Tamil Nadu. Asian Agri-History. 8(1): 55-61.

- Ravikumar RK, Rao BS, Bose CHS, Sudhakar K, Anjanappa (2002). Adoption of indigenous technical knowledge and its scientific rationale. Cheiron. 31(5-6): 109-113.

- Reddy BSS, Kumari KN, Reddy YR, Reddy MVB, Reddy BS (2014). Comparison of different diagnostic tests in subclinical mastitis in dairy cattle. Int. J. Vet. Sci. 3(4): 224228.

- Reyher KK, Dohoo IR (2011). Diagnosing intramammary infections: Evaluation of composite milk samples to detect intramammary infections. J. Dairy Sci. 94(7): 3387-3396.

- Syed AM, Digraskar SU, Awaz KB (2009). Evaluation of Buffalo milk with reference to Somatic cell count and Antitrypsin. Vet. World. 2(7): 267-268.

-Tripon A (2014). Innovative technology for sustainable development of human resource using non-formal and informal education. Procedia Technol. 12: 598-603. http:// dx.doi.org/10.1016/j.protcy.2013.12.535 